Journal of Learning and Development Studies (JLDS)

DOI: 10.32996/jlds

Journal Homepage: www.al-kindipublisher.com/index.php/jlds

\title{
Learning English in a Virtual Set-up: Motivations and Amotivations among Language Learners
}

\author{
Joyce V. Gonzales \\ College of Teacher Education, Western Mindanao State University, Zamboanga City, Philippines
}

Corresponding Author: Joyce V. Gonzales, E-mail: gonzalesjoyce143@gmail.com

\author{
ARTICLE INFO \\ Received: September 18, 2021 \\ Accepted: October 07, 2021 \\ Volume: 1 \\ Issue: 1 \\ DOI: $10.32996 / j$ lds.2021.1.1.3
}

\section{KEYWORDS}

Online-based learning, online language learning, motivation, amotivation, language learners.

\section{ABSTRACT}

The COVID-19 outbreak brought unprecedented challenges in the academe. Educational institutions transitioned to distance learning primarily through online and modular learning. Moreover, with the rapid development of online learning, one of the concerns in the field of online education is regarding students' motivation to learn and to stay engaged in an online environment. Thus, this present study aimed to determine the motivations and amotivations of language learners in online language learning. The participants of the study include seven language learners, who were selected through a purposive sampling method. A descriptive qualitative research design was employed, and individual in-depth interviews were conducted to gather the data. The responses were transcribed and analyzed through thematic analysis. Furthermore, it was found out in the interviews that the motivations of the respondents in learning English online include learning in a convenient set-up, creating a room for independent learning, utilizing online learning tools, apps, and resources, developing technological competence, watching multimedia videos for learning, and exploring the features of the educational applications. On the contrary, the limited interaction, less interactive activities, poor and unstable internet connectivity, less student participation, lack of comprehensive discussion of the lesson, rare opportunity to enhance speaking skills, absence or delayed feedback from the teacher, inconsiderate teachers towards students' situation, and the fact that online language learning can trigger procrastination and unproductivity are found to be the amotivations of the respondents in learning English online.

Published by Al-Kindi Center for Research and Development, London, United Kingdom.

Copyright (c) the author(s). This open access article is distributed under a Creative Commons Attribution (CC-BY) 4.0 license (https://creativecommons.org/licenses/by-nc-nd/4.0/)

\section{Introduction}

The shift of the learning platform to virtual set-up brought a change in the academe. In fact, the recent COVID-19 pandemic gave rise to a trend in setting up virtual classrooms for distance learning. A virtual classroom is an environment where both teachers and students can engage in the educational process in an online environment. Virtual classrooms are developed to promote a greater count of students into the field of education (Murugachandravel, 2019). Considering the evolving pace of online learning, providing a quality online instruction experience for students has been an utmost concern in the field of online education (Lee \& Martin, 2017). That being said, students' motivation to learn is a significant factor to achieve success when learning in an online environment (Artino, 2008). Supportive of this, Selvi (2010) maintained that motivation can be categorized as intrinsic and extrinsic motivation, and both of these are vital for students' engagement in the learning process.

Relative to this, motivation can impact how we are learning, what we are learning, and when we decide to learn (Schunk \& Usher, 2012, as cited in Hartnett, 2016). Hence, the amount of motivation that students possess can affect the process of their learning. Moreover, it is important to note that motivation mirrors students' decision of engaging in learning activities, the effort they exert, their determination on the learning activities, and how they cope up with the challenges they experience in the process of their learning (Bakar, 2014). In addition, students who have high levels of motivation are demonstrated by certain characteristics including having initiative, diligence and active learning, not easy to satisfy, punctuality and discipline, and continually learning with the best outcome (Baron \& Donn, 2000, as cited in Bakar, 2014). 
Several scholars have proposed that learners who study in an online environment require motivation, self-management to remain engaged, manage their learning, and direct their work (Dabbagh \& Kitsantas, 2004; Hartley \& Bendixen, 2001; Schunk \& Zimmerman, 1998, as cited in Artino \& Stephens, 2009). Hence, educators play a fundamental role in motivating the learners when learning in a virtual setup. Furthermore, motivation is noted to be an important construct that fosters a positive effect and improves students' learning in any second language learning context (Gholami, Allahyar, \& Rafik-Galea, 2012). In a similar vein, Cook (2000, as cited in Mahadi \& Jafari, 2012) claimed that the most crucial factor influencing second language acquisition is motivation. Therefore, learning English in an online environment requires learners to possess a significant amount of motivation to successfully learn the target language.

On top of that, students' feeling of amotivation when learning in an online environment is inevitable. Moreover, the absence of intrinsic and extrinsic motivation is associated with amotivation, wherein the students are unwilling to learn or have less motivation in learning (Gustiani, 2020). Additionally, amotivation also leads to having low self-efficacy, the feeling of being incapable, believing that one's action will have no good outcome, and placing a low value on the tasks that one needs to undertake (Hartnett, 2016). Supportive of this Chambers (1993, as cited in Yadav \& BaniAta, 2013) posited that various elements can cause students to be unmotivated and it functions differently with students under different circumstances. Hence, similar experiences that different students go through can have a contrasting impact on them.

Relatively, having low levels of motivation is recognized as a definitive element leading to students' withdrawal from online classes (Muilenburg \& Berge, 2005, as cited in Hartnett, 2012). Thus, it can be noted that poor motivation is an evident factor that leads to students' attrition in online learning. In addition, Dağgöl (2013) suggests that students who have poor self-confidence, high anxiety, and inhibition can adversely affect their motivation level. Hence, there is a need for teachers to figure out the factors that can cause amotivation among students which can impede their learning process. Apparently, learning in an online environment also imposes challenges that may affect students' learning motivation.

In the light of these findings, this present investigation aims to examine the motivations and amotivations of language learners in learning English online. Furthermore, it can be noted that there are studies that have been conducted in this area of interest. Studies like that of Fandino, Munoz, and Velandia (2019) conducted a qualitative investigation on motivation and online learning of English as a foreign language. Also, the study conducted by Ushida (2005), investigated students' attitudes and motivation in second language learning in online language courses. As a matter of fact, it is believed that motivation and learning have a significant correlative relationship (Brophy, 2010, as cited in Hartnett, 2016). Thus, motivation has been evidently investigated across various traditional academic realms (Schunk, Meece, \& Pintrich, 2014, as cited in Hartnett, 2016). However, the investigations which examine motivation in the context of online learning are limited in scope and number (Bekele, 2010).

Along with this, there is insufficient literature on the motivation and amotivation regarding online English language learning, whereas the majority of these studies revolve around the motivation when learning English in the context of a traditional classroom. Nevertheless, this study intends to delve into the motivations and amotivations of language learners in online language learning, to know what makes language learners motivated and unmotivated when learning English in a virtual set-up.

\section{Review of Related Literature}

\subsection{Online-based learning}

The integration of technology in delivering classroom instruction has been adopted by educators. With the advent of technology, online-based learning came into existence and several learning institutions recognized the ability of technology as a medium for classroom instruction. According to Dhull and Sakshi (2017), online-based learning is composed of different technologies such as email, chat, world wide web, new groups, and messages as well as audio and video teleconference which are all carried out through the help of computer networks for educational purposes.

In the study conducted by Gedera (2014), she claimed that an online learning environment can offer learners the opportunity to become flexible, interactive, and collaborative, which is different from a traditional learning environment. In addition, with good web-based learning applications or programs, students have the freedom to partake in class discussions, express opinions, and impart ideas equally regardless of the class size and time (Harasim, Calvert, \& Groeneboer, 1997, as cited in Kuama \& Intharaksa, 2016). It can be conceived that online-based learning allows both students and teachers to be actively involved in the educational process with the help of various educational applications and software. Hence, useful applications and software can motivate learners when learning online.

Along with this, some studies have revealed the other advantages of online-based learning. Some of these advantages include efficiency of expense and cost viability, life-long education and ease of learning, time efficiency, greater adaptability, less geographical boundaries, and better regulation (Hjeltnes et al., 2004, as cited in Al-maqtri, 2014). However, the integration of 
online educational technologies in the educational process can also lead to some challenges experienced by students and teachers that negatively affect students' motivation to learn.

Unarguably, both students and teachers are likely to encounter difficulties in an online mode of learning. Falloon (2012) contended that there is still a need for teachers to invest much time in order to teach students the effective utilization of multimedia tools that are available in virtual classrooms. Apart from this, Ahmad, Ghani, and Malik (2020) pointed out that the lack of connectivity, electronic devices, and slow internet may affect the success of an online mode of learning. Indeed, virtual set-up demands internet connectivity to connect with others and for online applications to function effectively. Thus, when the internet is slow, success in virtual classrooms may not be achieved. Eventually, these may induce problems in online language learning. Similarly, in the study of Daneshdoust and Hagh (2012), it was revealed that the learning process of students in internet-based learning can involve chaos. This is because teachers cannot control learners completely in an online environment. Thus, a development in the area of online-based environments to provide new forms of interaction for learners' learning experience is needed.

Virtual classrooms nowadays are utilized by educators to recreate the accustomed teaching practice for centuries. It is to teach in the same manner as teaching in a traditional classroom (Xenos, 2018). On the contrary, Hassenburg (2009) argued that directing student communication through the internet is challenging, and is not the same as dialoguing face-to-face. Hence, this is brought about by some factors such as slow internet connectivity and technical problems that hamper the flow of online communication which is also discouraging for online learners. Additionally, in the investigation conducted by Daneshdoust and Hagh (2012), it was found out that internet-based learning is less prominent compared to the traditional ways of learning, considering that during communication in a face-to-face environment, learners can see each other and it allows easier communication such as through their facial expressions. Thus, internet-based learning may cause difficulty in giving a detailed account of the learners' recognition.

Furthermore, the ever-growing popularity of online-based learning is still a work in progress, and it brought definite advantages and disadvantages to the educational phenomenon. Hence, this investigation will further explore how these advantages and disadvantages in online-based learning can result in the motivations and amotivations of language learners when learning English in a virtual set-up.

\subsection{Motivation in online language learning}

Motivation can be referred to as stimulating excitement in the students' minds to receive instruction (Crump, 1995, as cited in Brewer \& Burgees). In a similar vein, Lumsden (1994) maintained that student motivation is directed to students' interest to be engaged in the educational process. Furthermore, the different motivation types in language learning were investigated by various researchers.

Relative to this, Gardner and Lambert (1972) found out the essential role of motivation in language learning, where they pointed out that motivation has two different types. First, is the integrative motivation which is a type of motivation that reflects the personal desire of students to learn the language of other people, and to better understand their culture; second, is the instrumental motivation that emphasizes learning a language for the practical advantages and value (Gardner, 1985, as cited in Nguyen, 2019). Furthermore, another concept regarding motivation was initiated by Ryan and Deci (2000a) which is the SelfDetermination Theory, wherein they distinguish the various types of motivation in accordance to the different reasons or objectives that result in action. Intrinsic motivation is the act of accomplishing something because one finds it enjoyable, while extrinsic motivation is the act of accomplishing something because it results in a separable consequence.

On another note, the important role of motivation in an online learning environment was investigated by researchers. Studies show that motivated learners are more willing to take part in difficult activities, have an active engagement, enjoy and embrace a profound way to deal with learning, and demonstrate improved performance, perseverance, and creativity (Ryan \& Deci, 2000b). Therefore, to be able to build a more active environment for online discussion that advances active participation of learners, it is important to determine which qualities encourage the learners to stay engaged during the learning process (Lee \& Martin, 2017).

Various researches have shown that online-based learning requires a great amount of self-regulation and motivation (Golladay et al., 2000; Serwatka, 2003, as cited in Yuyun, 2013). Students with high levels of motivation and good self-management skills were more likely to achieve success when learning in virtual classrooms (Barbour \& Reeves, 2009, as cited in Lin, Zhang, \& Zheng, 2017). Corroborating this, Kerr, Rynearson, and Kerr (2006) found out that the characteristics of a successful online student include being autonomous, independent, responsible for one's learning, self-competent, has reading and writing proficiency, time regulation, and motivation to learn. Thus, these qualities will be of great help for students to successfully take part when learning in an online environment. 
Undeniably, learning English in a virtual set-up has its advantages which can positively affect students' motivation to learn. Through the years, the utilization of the internet has provided unprecedented opportunities for learners, most especially for language learners (Topkaya \& Erarslan, 2017). Thus, learning English online provides advantages for second language acquisition. Chalak and Jamalifar (2014) stated that the internet is a useful means for learning English and linguistic terminologies. In fact, Blake (2011) suggested that with the internet, language learners have numerous educational applications and programs to choose from that can help them with their online language learning such as "Quia" and "Hot Potatoes." Additionally, it also provides flexibility (Dimora \& Nedeva, 2010) because it enables learners to study anywhere, anytime, and work at their own pace as long as they have digital technologies with internet connectivity. Moreover, learning in an online environment provides a plethora of fun games and activities that promote second language learners' learning motivation (Lai \& Kristonis, 2006). Therefore, the utilization of technology for students' learning stimulates their motivation to learn in a virtual set-up given its benefits in language learning.

As the COVID-19 pandemic continues to rise, online-based learning remains to be a new form of learning modality. Moreover, learning in an online environment has its benefits that would be of great help for learners, and that will motivate them to learn, given the advantage of the internet where they can utilize online applications and resources to help them with their learning. Hence, exploring the motivations of language learners when learning in a virtual set-up is significant since motivation is an essential factor that allows learners to be engaged in the educational process.

\subsection{Amotivation in online language learning}

Amotivation is viewed as the shortfall of motivation that results from a person's feelings of inability and incompetence of accomplishing a task, and not because of the absence of starting interest (Deci \& Ryan, 1985, as cited in Chong, Renanda, \& Ng, 2019). Similarly, amotivation is also ascribed to four sources including the lack of belief in one's capacity to work on a task, finding the strategies ineffective, thinking that the task requires too much effort, and having a perception that one's effort is not sufficient to accomplish the task to be done (Vallerand, 1997).

Along with this, it is inevitable for students to experience amotivation when learning in an online environment. As schools transitioned to distance learning, one of the concerns of educators is regarding students' motivation to learn in an online environment. Corroborating this, Pekrun (2006) maintained that the stress and anxiety brought by the COVID-19 pandemic may result in a lack of motivation and less student engagement with their learning as previous studies have revealed that negative emotions may impede the learning of students.

Some foregoing investigations have shown that that the absence of time and motivation are the common reasons that result in learners' withdrawal in online courses (Aragon \& Johnson, 2008; Serwatka, 2005; Visser, Plomp, Amirault, \& Kuiper, 2002, as cited in Kim \& Frick, 2011). This only means that the lack of motivation is one of the factors contributing to students' unwillingness to attend classes in an online environment. Additionally, in the study conducted by Kuama and Intharaksa (2016), findings have shown that limitations in online language learning include less interaction, reduced direct feedback, lack of training in using the needed technology, and fewer opportunities for learning and performing the skills essential for language learning. Therefore, these challenges faced by students when learning English in a virtual set-up adversely affect their motivation to learn.

Furthermore, the other concerns in online-based learning include the quality in the delivery of instruction, assessments, technological limitations, and many more which may lead to less student motivation in learning or improving their education (Riel \& Polin, 2004; Schwen \& Hara, 2004, as cited in Krishnan et al., 2020). In addition, learners who are used to learn in a traditional face-to-face set-up when shifting through the complex domains of the online environment also result in attrition and cause learners to become unmotivated (Dubey \& Piroska, 2019, as cited in Soni \& Dubey, 2019). Hence, it can be drawn that the sudden shift of the traditional classroom set-up to a virtual set-up may contribute to students' disengagement when learning in an online environment.

Although online language learning offers benefits for language learners, it can be perceived that there are various limitations and challenges experienced by learners when learning in an online environment. Thus, this may contribute to learners' amotivation to learn in an online environment which may also lead to their withdrawal from online learning. Therefore, this study involves an investigation regarding the amotivations of language learners in online language learning, to determine the causes of their reduced motivation to learn online.

\subsection{Research Questions}

The present investigation aims to answer the following research questions: 
1. What are the motivations of the respondents in learning English online?

2. What are the amotivations of the respondents in learning English online?

\section{Methodology}

\subsection{Research Design}

This current research investigation employs a qualitative research design. Major and Savin-Baden (2010, as cited in Blackmon \& Major, 2012) stated that qualitative is an essential tool for multiple reasons. It offers an understanding of a specific situation that relays stories rather than determining reasons and consequences (Yang \& Cornelius, 2004). Such as in the case of this research study which carries the objectives of identifying the motivations and amotivations in online English learning among language learners. Thus, qualitative research is viewed as the appropriate method for the study as it provides the researcher the window of opportunity to comprehend respondents' perspectives.

\subsection{Participants of the study}

This investigation includes a total of seven language learners from the College of Teacher Education (CTE) of Western Mindanao State University (WMSU) taking up a bachelor's degree major in English. Moreover, two of the said respondents were males, while five were females with ages ranging from 21-22. In this investigation, the researcher utilizes a purposive sampling method for the selection of the respondents. Thus, the researcher decides who can give information on the account of knowledge and experience (Bernard, 2002, as cited in Ramos et al., 2020). Additionally, this includes the selection of individuals that are knowledgeable in the subject of interest (Cresswell \& Plano Clark, 2011, as cited in Alkassim, Ettikan, \& Musa, 2016). Furthermore, the researcher established the following inclusion criteria for the selection of the respondents: (1) the respondent must be a student enrolled in the course of education, English as an area of specialization, (2) the respondent must be part of the present online-based educational system. Otherwise, he/she could not be part of the research investigation.

\subsection{Research Instrument}

To determine the motivations and amotivations of language learners in virtual learning of the English language, a qualitative approach was employed through a semi-structured interview. Jamshed (2014) defined semi-structured interviews as those indepth interviews wherein the respondents need to answer open-ended questions. Thus, respondents were provided open-ended questions to gather their different views and opinions related to the topic. In so doing, the instrument is authorized to attain valid responses from the participants. The interview consists of four questions dealing with their motivations and amotivations when learning English in a virtual set-up.

\subsection{Data Gathering Procedure}

After the development of the interview questions, participants were messaged through chat informing them about the current investigation and seeking their consent for participation. Participants who consent to take an interest provided a schedule for a phone call interview. The researcher conducted a semi-structured interview through phone calls among the respondents. The interview lasted for about 15-20 minutes for each respondent. All the responses were audio-recorded and transcribed. The transcripts of the responses were transferred in MS Excel for the analysis and interpretation of the results. Moreover, the researcher will develop themes based on the respondents' perceptions and experiences that the researcher view as pertinent to the research question. The gathered data will be analyzed through the development of themes.

\subsection{Method of Analysis}

The current investigation employs thematic analysis in analyzing the data of the study. As argued by Moules, Norris, Nowell, and White (2017) thematic analysis is a qualitative research method that can be utilized across a wide range of epistemologies and research queries. In fact, thematic analysis is a helpful technique for analyzing different perspectives of the respondents and in developing insights (Clarke, 2006; King, 2004, as cited in Moules et al., 2017).

\section{Results and Discussion}

The researcher was able to develop themes that appeared in the data on the interview. It was shown in tables 1 and 2 that the themes present in the data are the grounds for examining the motivations and amotivations of language learners in learning English in a virtual set-up. Table 1 provides the motivations in online language learning while table 2 presents the amotivations in online language learning.

Table 1: Motivations in Online Language Learning 


\begin{tabular}{|c|c|c|}
\hline Themes & Percentage & Excerpts \\
\hline $\begin{array}{l}\text { 1. Learning in a convenient set- } \\
\text { up }\end{array}$ & $\begin{array}{l}6 \text { out of } 7 \text { or } \\
85.71 \%\end{array}$ & $\begin{array}{l}\text {...you get the chance to learn English at the confines of your } \\
\text { home...you don't have to commute every day; all you have to do } \\
\text { is to sit and find a perfect spot and feel comfortable while } \\
\text { listening to the teacher... I feel that I am not trapped in the four } \\
\text { walls of our classroom and I can still do other } \\
\text { things at my home. (Respondent 1) } \\
\text { Before I really need to endure my long travel to school and } \\
\text { vice-versa since my home address is really far from } \\
\text { school...Just being thankful that I am doing homeschooling } \\
\text { now and it makes me feel motivated because I can decide the } \\
\text { place where to study and I make myself comfortable. } \\
\text { (Respondent 6) }\end{array}$ \\
\hline $\begin{array}{l}\text { 2. Creating a room for } \\
\text { independent learning }\end{array}$ & $\begin{array}{l}4 \text { out of } 7 \text { or } \\
57.14 \%\end{array}$ & $\begin{array}{l}\text {...It gives me a more individualized phase in learning which } \\
\text { means that I am more of becoming independent than I was } \\
\text { before because in online learning everything is not yet given to } \\
\text { us easily...materials and instructions are given to us but it's up to } \\
\text { us to study, to further do some research on that particular lesson. } \\
\text { Because during one particular online class that we have, our } \\
\text { teacher does not give everything... after the discussion, it's up to } \\
\text { us to read the document, to search for more details about the } \\
\text { subject matter or the lesson. (Respondent 4) } \\
\text {...unlike the traditional face-to-face instruction, this virtual set-up } \\
\text { allows us to perform several activities and usually, individual } \\
\text { activities...it is teaching me to become more independent this } \\
\text { time...most of the teachers are fond of giving individual activities } \\
\text { and most are written so I learned to really work on my own. } \\
\text { (Respondent 6) }\end{array}$ \\
\hline $\begin{array}{l}\text { 3. Utilizing online learning tools, } \\
\text { apps, and } \\
\text { resources }\end{array}$ & $\begin{array}{l}5 \text { out of } 7 \text { or } \\
71.43 \%\end{array}$ & $\begin{array}{l}\text { Before during our face-to-face classes, we only conform to the } \\
\text { traditional means of learning. Learning through textbooks, } \\
\text { learning through traditional materials. In the new platform that } \\
\text { we have right now, with online learning we are introduced to } \\
\text { different tools and applications that we can afford to utilize to } \\
\text { further enhance our learning. (Respondent 4) }\end{array}$ \\
\hline & 2 out & $\begin{array}{l}\text {...there are sources available where I can learn English easily just } \\
\text { like Google, YouTube, and other websites. If I want to learn } \\
\text { grammar, I can look for credible articles and journals on Google } \\
\text { and different websites. If I want to learn how to properly } \\
\text { pronounce words, I can just watch it on YouTube. So basically, } \\
\text { the language learning materials are readily available online. } \\
\text { (Respondent 5) }\end{array}$ \\
\hline
\end{tabular}




\begin{tabular}{|c|c|c|}
\hline $\begin{array}{l}\text { 4. Developing technological } \\
\text { competence }\end{array}$ & $28.57 \%$ & $\begin{array}{l}\text {... I could probably get to experience...how does it feel to explore } \\
\text { the world of technology since we are already in the 21st century. } \\
\text { It is really important to us to have experiences when it comes to } \\
\text { technology-driven platforms because as future teachers we also } \\
\text { have to be technology savvy wherein probably in the future we } \\
\text { will also be conducting online classes at least we already have } \\
\text { the experience to teach online and for me, that is an advantage. } \\
\text { (Respondent 3) } \\
\text { s..I am part of the } 27 \text { st-century learners so I need to develop the } \\
\text { skills and competence that I have. One of which is technological } \\
\text { competence. As a prospective language teacher, I need to be } \\
\text { flexible when it comes to the teaching modality and teaching } \\
\text { styles that I will be employing in the near future...my knowledge } \\
\text { should not only be limited to the traditional forms of teaching } \\
\text { styles...I need to know how to use MS word, excel, Google } \\
\text { classroom, Google meet, and MS Teams so that I will be used to } \\
\text { this kind of platform. And in the near future, if I will be immersed } \\
\text { in online learning like this, of course, I know how to deal with it, } \\
\text { and I know how to cope up with the situation because I already } \\
\text { have the skill and competence. (Respondent } 4 \text { ) }\end{array}$ \\
\hline $\begin{array}{l}\text { 5. Watching multimedia videos } \\
\text { for learning }\end{array}$ & $\begin{array}{l}1 \text { out of } 7 \text { or } \\
14.29 \%\end{array}$ & $\begin{array}{l}\text {...teachers in this online platform use a lot of multimedia and } \\
\text { they direct us to videos. They often ask us to watch YouTube } \\
\text { where students can really relate to it, and it is something that } \\
\text { resonates with our generation which our teachers in the online } \\
\text { classroom really use, and it's interesting. (Respondent 1) }\end{array}$ \\
\hline $\begin{array}{l}\text { 6. Exploring the features of the } \\
\text { educational applications }\end{array}$ & $\begin{array}{l}2 \text { out of } 7 \text { or } \\
28.57 \%\end{array}$ & $\begin{array}{l}\text { The features that I like in the app...it easy for you to pass your } \\
\text { activities, assignments, and you do not have to access other } \\
\text { websites or other apps just for you to take quizzes or to do } \\
\text { activities. It's just like one app then all the features are there } \\
\text { whether you want to chat with your teacher, or you want to read } \\
\text { the lectures it's all there in one app. (Respondent 7) }\end{array}$ \\
\hline
\end{tabular}

Table 1 shows the motivations of the respondents in online language learning. The data shows that there are six themes provided.

\subsection{Learning in a convenient set-up}

Based on the data, the first one is learning in a convenient set-up including the time and location. Six out of the seven or $85.71 \%$ of the respondents are motivated to learn English in a convenient learning environment.

The excerpts below point out to this idea:

\section{Respondent 1}

"I can learn the English language even though I am just at home...through online I am the one who holds my time since I can access the lesson and learn the language anytime."

\section{Respondent 4}

"...when I am at home, I have other things to do just like some household chores. But because we are just having this class online, it's convenient on my part because I can have the class at any place that I want, at 
any corner of my home, and I can have it outside as long as I am comfortable, as long as I can effectively and efficiently learn during that time."

This implies that online language learning can be convenient for students considering that it can be done at home, and there is no need for them to go to school most especially for those residing far from their school. Also, they have much time to do other stuff at the confines of their home. Moreover, this perspective is supported by Murugachandravel (2019) who maintained that virtual classrooms go beyond the boundaries of time and location for it offers a flexible and inclusive learning environment. Similarly, Khan et al. (2021) claimed that online learning allows students to have the freedom to connect with their teachers, and classmates, and be engaged in learning with comfort and flexibility. Thus, schools and universities can benefit from virtual classrooms since it is a good way for teachers to teach students from different locations without any trouble.

\subsection{Creating a room for independent learning}

The respondents also believed that online language learning creates room for independent learning. This can be evidently seen as four out of seven or $57.14 \%$ of the respondents manifested the same thought. Respondent six suggests that virtual learning allows one to perform several individual activities and teaches one to become more independent since most of the teachers are fond of giving individual activities.

The following is the extract:

\section{Respondent 6}

"...unlike the traditional face-to-face instruction, this virtual set-up allows us to perform several activities and usually individual activities...it is teaching me to become more independent this time...most of the teachers are fond of giving individual activities and most are written so I learned to really work on my own."

This implies that online language learning enables students to be independent due to the fact that online language learning focuses more on self-paced learning without the full assistance of the teacher. This perspective is validated by Tanveer (2011, as cited in Banditvilai, 2016) in his study, it was revealed that teachers and students recognize online-based learning as an aid to students that enables them to be responsible for their learning by allowing them to become independent and have self-confidence.

\subsection{Utilizing online learning tools, apps, and resources}

The respondents also asserted that there are a variety of available online tools, apps, and resources in which they can utilize for online language learning. Five out of seven or $71.43 \%$ of the respondents expressed the same thought. This implies that the internet has a great advantage that motivates learners in the online language learning modality for it encompasses a variety of online learning tools and websites that can be of help for language learning. Supportive of this idea, Blake (2011) stated that with the internet, language learners have numerous educational applications and programs to choose from, that would be beneficial for the online language learning process. Additionally, Mohd Salman and Aziah (2012) claimed that online learning offers interactive materials which give access to information and allows easy responses from others. Hence, these accessible online materials provide aid to students in their online learning process.

\subsection{Developing technological competence}

Two out of seven or $28.57 \%$ of the respondents noted that online language learning can develop their technological competence. Respondent three maintained that it is important for future teachers to have experiences when it comes to technology-driven platforms and be technology savvy since there is a possibility of conducting online classes in the future. Furthermore, respondent four shared the same idea.

The excerpt below highlights this idea:

\section{Respondent 4}

"I am part of the 21st-century learners so I need to develop the skills and competence that I have. One of which is technological competence. As a prospective language teacher, I need to be flexible when it comes to the teaching modality and teaching styles that I will be employing in the near future."

This perspective is validated by Kim and Frick (2011), who revealed that learning in an online environment is practical and students will more likely become motivated to learn since E-learning can develop their competence in the use of technology, and enables them to be engaged in the educational process. This implies that learning in a virtual environment gives an opportunity for students to be acquainted with the use of technology that would benefit them in the near future as professionals. 


\subsection{Watching multimedia videos for learning}

One of the respondents pointed out that learning English online allows teachers to integrate multimedia videos to be used for students' learning. Respondent one suggests that teachers use a lot of multimedia and they direct students to watch videos to which students can relate, and it is something that resonates with their generation. Corroborating this, Januszewski and Molenda (2008, as cited in Ashton, 2014) maintained that the utilization of video technology has the likelihood to attract the senses. Hence, it can be noted that students become more motivated when videos are being utilized as their learning material since today's generation is inclined to watching videos or video clips as a result of the advancement of modern technologies.

\subsection{Exploring the features of the educational applications}

Lastly, two out of the seven respondents asserted that there are various features of the educational applications that are utilized in online language learning. Respondent seven posited that there are features of the educational applications that allow students to submit assignments, and activities as well as a chat feature that enable students to send a private message to their teacher. Thus, all these things can be done with ease in just one application. This perspective is validated by Harasim, Calvert, and Groeneboer (1997, as cited in Kuama \& Intharaksa, 2016), who maintained that with good web-based learning applications or programs, students have the freedom to partake in class discussions, express opinions, and impart ideas equally regardless of the class size and time. This only means that online language learning allows students to utilize such educational applications, and explore its unique features that can help them with their learning.

Table 2: Amotivations in Online Language Learning

\begin{tabular}{|c|c|c|}
\hline Themes & Percentage & Excerpts \\
\hline $\begin{array}{l}\text { 1. Limited interaction } \\
\text { between the teacher } \\
\text { and the students }\end{array}$ & $\begin{array}{l}3 \text { out of } 7 \text { or } \\
42.86 \%\end{array}$ & $\begin{array}{l}\text {...it gives us a lesser engagement, lesser interaction with the } \\
\text { teacher...there is an absence of active learning...the students } \\
\text { during online classes are not that active learners, they are more } \\
\text { of becoming passive learners. Of course, when you are having } \\
\text { online classes, the teacher is not really sure if the students are } \\
\text { listening that's why some of the teachers really request students } \\
\text { to turn on their cameras to make sure and ascertain that } \\
\text { students are listening and not doing any unnecessary things. } \\
\text { (Respondent 4) }\end{array}$ \\
\hline $\begin{array}{l}\text { 2. Less interactive } \\
\text { activities given }\end{array}$ & $\begin{array}{l}1 \text { out of } 7 \text { or } \\
14.29 \%\end{array}$ & $\begin{array}{l}\text {...there are fewer activities on this platform. Compared to the } \\
\text { traditional classroom, we are given multiple activities like } \\
\text { groupings and other tasks. But in this online platform, what we } \\
\text { do is simply listen and we are given activities that we answer on } \\
\text { our own... because of that, the fewer activities and less } \\
\text { participation, there is less retention. (Respondent 1) }\end{array}$ \\
\hline $\begin{array}{l}\text { 3. Poor and unstable internet } \\
\text { connectivity }\end{array}$ & $\begin{array}{l}6 \text { out of } 7 \text { or } \\
85.71 \%\end{array}$ & $\begin{array}{l}\text {...When there is a poor internet connection, it really affects. } \\
\text { When the teacher had a poor internet connection, it's } \\
\text { something that discourages the students like me, and } \\
\text { sometimes I am the one who has a poor internet connection, it's } \\
\text { discouraging on my part to enter the class and to really stay } \\
\text { focus. (Respondent 1) }\end{array}$ \\
\hline & & $\begin{array}{l}\text {...I experience poor internet connectivity wherein it's really hard } \\
\text { when I have to attend video conferences especially when there } \\
\text { are presentations. It really scares me sometimes and it makes }\end{array}$ \\
\hline
\end{tabular}




\begin{tabular}{|c|c|c|}
\hline & & $\begin{array}{l}\text { me anxious due to a weak internet connection. I cannot attend } \\
\text { my classes very well because at my end the teacher sounds } \\
\text { choppy so I cannot really comprehend what the teacher } \\
\text { discusses or what my classmates are trying to say. (Respondent } \\
\text { 3) } \\
\text {...the slow, unstable internet connectivity that we have. Of } \\
\text { course, we cannot control the internet connection but the } \\
\text { problem here is I cannot learn properly... when I am on the meet } \\
\text { and the teacher gets cutting and the internet, the signal is not } \\
\text { cooperating. I start getting disconnected instead of getting } \\
\text { connected to the lesson, and because I get disconnected a } \\
\text { couple of times, I was not able to listen to the discussion, with } \\
\text { the teacher especially if she shares some announcements. } \\
\text { (Respondent 4) }\end{array}$ \\
\hline $\begin{array}{l}\text { 4. Less student } \\
\text { engagement and participation }\end{array}$ & $\begin{array}{l}1 \text { out of } 7 \text { or } \\
14.29 \%\end{array}$ & $\begin{array}{l}\text {...there are times that the class seemed so silent and nobody is } \\
\text { participating and it's demotivating as a student to see that your } \\
\text { classmates not participating, and you, yourself seemed so silent } \\
\text { and the whole class is not active so it's something that is not } \\
\text { really good, it's demotivating on my part. (Respondent 1) }\end{array}$ \\
\hline $\begin{array}{l}\text { 5. Lacks a comprehensive } \\
\text { discussion of the lesson }\end{array}$ & $\begin{array}{l}4 \text { out of } 7 \text { or } \\
57.14 \%\end{array}$ & $\begin{array}{l}\text {...some of the teachers failed to do in the course of online } \\
\text { learning...is that some of them do not comprehensively discuss } \\
\text { the lesson and they just read. They failed to give some } \\
\text { elucidation or explanation they just simply relay the } \\
\text { information without further information about it. (Respondent } \\
\text { 2) }\end{array}$ \\
\hline & & $\begin{array}{l}\text {...when the topic is really complex and I cannot understand it } \\
\text { well, it's really difficult for me to understand the lesson } \\
\text { therefore, I have to do a lot of research and I really have to } \\
\text { search for related articles to supply the knowledge that I have in } \\
\text { order for me to understand the lesson. (Respondent 5) } \\
\text {..there are teachers who give a lot of activities but do not really } \\
\text { teach. When they give the activity, they just expect you to } \\
\text { answer the activity and then be done. The next week, they are } \\
\text { not going to explain what you have done or what they have } \\
\text { given you...they do not explain the lecture they give; they just } \\
\text { give another activity. (Respondent 7) }\end{array}$ \\
\hline $\begin{array}{l}\text { 6. Rare opportunity to } \\
\text { enhance speaking skills }\end{array}$ & $\begin{array}{l}1 \text { out of } 7 \text { or } \\
14.29 \%\end{array}$ & $\begin{array}{l}\text {...we as language majors believe that both of our written and } \\
\text { speaking skills should be developed. However, as I have } \\
\text { observed in this kind of set-up, it's more on written activities, } \\
\text { more on essays, analysis, and critiques and we are rarely given } \\
\text { the opportunity to speak. I think my speaking skills tend to lag } \\
\text { behind and only my written skills are constantly being } \\
\text { practiced. (Respondent 6) }\end{array}$ \\
\hline
\end{tabular}




\begin{tabular}{|c|c|c|}
\hline $\begin{array}{l}\text { 7. Absence or delayed } \\
\text { feedback from the teacher }\end{array}$ & $\begin{array}{l}2 \text { out of } 7 \text { or } \\
28.57 \%\end{array}$ & $\begin{array}{l}\text {...teachers' responses are delayed. For example, our teacher } \\
\text { gives us an activity, and then the instructions are vague and not } \\
\text { really clear...we asked the teacher through messenger but the } \\
\text { response is few days after we asked the question. (Respondent } \\
\text { 4) }\end{array}$ \\
\hline $\begin{array}{l}\text { 8. Inconsiderate teachers } \\
\text { towards students' situation }\end{array}$ & $\begin{array}{l}1 \text { out of } 7 \text { or } \\
14.29 \%\end{array}$ & $\begin{array}{l}\text {... have encountered some teachers who keep on giving } \\
\text { activities to meet and they give no feedback. We receive no } \\
\text { feedback from the teachers so we are not sure if we are doing } \\
\text { the right thing or if something needs to be corrected. } \\
\text { (Respondent 6) } \\
\text {...there are teachers who are not considerate in the situation of } \\
\text { their students... when most of our classmates were experiencing } \\
\text { poor internet connection due to the bad weather but she } \\
\text { insisted on continuing the class. Instead of comforting the class } \\
\text { by saying "it's okay, it's fine", she got mad at us and she } \\
\text { complained about it like we can do something but we can't and } \\
\text { it's not our fault. (Respondent 7) }\end{array}$ \\
\hline $\begin{array}{l}\text { 9. Triggers procrastination and } \\
\text { unproductivity }\end{array}$ & $\begin{array}{l}1 \text { out of } 7 \text { or } \\
14.29 \%\end{array}$ & $\begin{array}{l}\text {...I try to be more procrastinate or shall I say I become more } \\
\text { unproductive when I learn English online. With online learning, I } \\
\text { procrastinate and do the activities, do the home works, read the } \\
\text { documents the next day or after the next day. I become more } \\
\text { unproductive when I am just at home compared to the } \\
\text { traditional or face-to-face classes. (Respondent 4) }\end{array}$ \\
\hline
\end{tabular}

Table 2 presents the amotivations of the respondents in online language learning. The data shows that there are nine themes provided.

\subsection{Limited interaction between the students and the teacher}

Firstly, is the limited interaction between the students and the teacher. Three out of seven or $42.86 \%$ of the respondents noted that online language learning limits their interaction with the teacher.

The extract below points out this idea:

\section{Respondent 1}

"...there is less interaction coming from both the teacher and the student...I cannot see the reaction of my teachers and my classmates."

This idea is supported by the claim of Fullerton, Taylor, and Watson (2009), who contended that online learning lessens the interaction between teachers and learners. In a similar vein, Daneshdoust and Hagh (2012) revealed that internet-based learning is less prominent compared to the traditional ways of learning, considering that during communication in a face-to-face environment, learners can see each other and it allows easier communication such as through their facial expressions. This implies that learning English in an online environment imposes challenges such as having limited student-teacher interaction as well as limited communication which results in the reduced motivation of students to learn English online.

\subsection{Less interactive activities given}

One of the respondents claimed that there are fewer interactive activities given when learning English online. Respondent one explained that in the online platform, there are fewer activities given, and students are only given activities that they will accomplish on their own. Whereas compared to the traditional learning setup, students are given multiple activities which involve group 
activities. Corroborating this, in the study conducted by Jan (2020), it was revealed that in online learning, there are too many assignments and individual activities given to students. This only means that students become unmotivated to learn in a virtual set-up whenever they are only given individual activities to work on. Thus, activities should be engaging and interactive.

\subsection{Poor and unstable internet connectivity}

The respondents also believed that online language learning imposes problems in internet connectivity. This can be evidently seen as six out of seven or $85.71 \%$ of the respondents expressed the same perspective. Respondent six posited that the slow internet connection causes difficulty for students to attend online classes. Also, it hinders student participation in class discussions since the poor internet connectivity results in a communication barrier because the teacher and the student may not understand each other when speaking due to the unstable internet connection.

The excerpt below is evidence:

\section{Respondent 6}

"...It's the slow connection in my area which makes me hard to attend classes mostly. It also hinders me from participating because usually, the teacher would tell me that he/she cannot understand what I'm saying. That's why sometimes I feel discouraged because of the poor signal...every day the signal is very poor..."

This only means that poor and unstable internet connectivity discourages students from online language learning. Apparently, slow internet connectivity appears to be the most frequent theme in the data. As the Philippines is reported to have the slowest internet connection in Asia (Akamai, 2011, as cited in Tria, 2020). Moreover, respondent seven also explained that poor internet connection is not a new problem for students living in rural areas.

Below is the extract:

\section{Respondent 7}

"...I'm currently located in a rural area wherein...poor internet connection is not new, and the signal outage is not new also. There are times that when I tried to attend class but the signal is not doing very well so I have to wait for five to ten minutes just for me to enter the class and sometimes I cannot enter the class because the signal is not enough to do so.

It can be noted that those students from rural areas are struggling with a very slow internet connection due to their current location. This is validated by Martinez and Esparcia (2020), who maintained that the limited internet access is a result of orography which is a factor for poor territorial coverage.

\subsection{Less student engagement and participation}

One of the respondents asserted that there is less student engagement and participation when learning in a virtual set-up. Respondent one explained that there are times that the students do not participate in the class discussion and the whole class seemed so silent. According to Everett (2015), it was found out in the survey conducted by The National Survey of Student Engagement (NSSE) that students who are taking up online courses were less engaged in cooperative learning. This implies that students when learning English online become passive learners than active learners, and have less interest to engage in class discussions.

\subsection{Lacks a comprehensive discussion of the lesson}

The respondents also noted that online English classes are limited in terms of providing a comprehensive discussion of lessons. Four out of seven or $57.14 \%$ manifested the same idea. Thus, it can be noted that there are professors that do not explain the lessons comprehensively online. Perhaps, some professors are still hesitant to accept conducting classes online and are still in the process of adjusting to this new modality. This observation is shared by the claim of Lai and Kristonis (2016), that teachers most especially faculty members of today do not have technological knowledge and are reluctant to accept the concept of online learning (Islam, Chowdhury, \& Islam, 2009). Additionally, Jan (2020) pointed out that one of the concerns in online learning is the teacher's inexperience when it comes to the delivery of the lesson online. Hence, teachers are not yet accustomed to the use of online apps and tools for online teaching which makes it difficult for them to impart the lessons and lectures to the students.

\subsection{Rare opportunity to enhance speaking skills}


One of the respondents remarked that online language learning provides a rare opportunity to enhance the speaking skills of students. Respondent six explained that in a virtual set-up the teachers provide students with several written activities such as essays, analysis, and critiques. Students are rarely given the opportunity to speak. This implies that providing a lot of written activities to students will not help them enhance their speaking ability but can only aid their writing ability. Mohammadi, Ghorbani, and Hamidi (2011) posited that an online learning setup enables learners to improve their writing skills in the target language. However, it is something that unmotivated them since language learners should also enhance their speaking skills as prospective language teachers.

\subsection{Absence or delayed feedback from the teacher}

Two out of seven or $28.57 \%$ of the respondents also believed that learning English online lessens the demand for immediate feedback from the teacher. As a result, it limits the teachers' direct guidance to students. Eventually, learners might be left with little or no learning at all in their English classes online. Respondent six maintained that some teachers kept on giving written activities for students to comply, however they do not even provide feedback to students after they have accomplished the activities. This may be true as online learning lessens the immediate feedback and interaction between teachers and learners (Fullerton et al., 2009) and reduces teachers' supervision of students (Mohammadi et al., 2011). Thus, this kind of practice discourages students since they cannot ascertain whether they have done the right thing or not.

\subsection{Inconsiderate teachers towards students' situation}

One of the respondents noted that there are some inconsiderate professors towards students' situations in this online learning setup. In fact, Brooks (2003, as cited in Kebritchi, Lipschuetz, \& Santiague, 2017) revealed that a primary concern affecting the teaching process in online classes is the instructor's attitude. Similarly, Dağgöl (2013) maintained that the negative attitude of teachers towards students and obstructive classroom environments reduce students' interest to learn the lesson. Respondent seven explained that a professor still insisted on continuing the online class discussion even though most of the students are experiencing problems in internet connectivity due to the bad weather condition. Thus, this kind of situation is discouraging on the part of the students since teachers are supposed to understand that the problem with internet connectivity is inevitable and is beyond students' control.

\subsection{Triggers procrastination and unproductivity}

Lastly, one of the respondents also asserted that online language learning can trigger procrastination and unproductivity. Respondent four posited that in the online learning modality, he tends to be more procrastinate and unproductive compared to the traditional set-up since the learning set-up is only at home, the activities, assignments, and other school-related stuff can be done anytime.

The respondent further explained:

\section{Respondent 4}

"...it is because I know I have more time; I know I control my time. However, I become lazier because instead of doing the things that I need to prioritize for my study, I am into other things like playing online games, doing unnecessary things."

This implies that learning English in a virtual set-up can make students unproductive by delaying the accomplishment of school tasks since the learning set-up is only at home thus, giving them the chance to procrastinate. Furthermore, procrastination is also a result of having a lack of intrinsic motivation and reduced self-regulation (Rakes \& Dunn, 2010, as cited in Yilmaz, 2017).

\section{Conclusion}

The current investigation examined the motivations and amotivations of language learners in online language learning. Evidently, the research data shows that the respondents have diverse perspectives toward learning English in a virtual set-up. Based on the data presented in the study, the following conclusions are constructed.

It can be noted that the motivations of language learners in online language learning include learning in a convenient set-up, creating a room for independent learning, utilizing online learning tools, apps, and resources, developing technological competence, watching multimedia videos for learning, and exploring the features of the educational applications.

On another note, the amotivations of language learners in online language learning involves the limited interaction between the students and the teacher, less interactive activities given, poor and unstable internet connectivity, less student engagement and participation, lack of comprehensive discussion of the lesson, rare opportunity to enhance speaking skills, absence or delayed 
feedback from the teacher, inconsiderate teachers towards students' situation, and the fact that online language learning can trigger procrastination and unproductivity.

Furthermore, this investigation revealed that the main motivation of language learners in online learning of English is the convenient learning set-up, wherein six out of seven respondents manifested the same thought. On the other hand, the most occurring amotivation of language learners in online learning of English is the poor and unstable internet connectivity, wherein six out of seven respondents expressed the same perspective.

\section{Implications}

The yielded findings of the study provide educational implications, presented as follows:

Firstly, schools and universities must provide more teacher training and seminars regarding online classes, specifically how to effectively conduct engaging and interactive online class sessions and activities for students. Hence, it is evident that several students have less motivation and participation in a virtual classroom compared to the traditional classroom. In addition, teachers should also maintain the practice of promoting a conducive and non-threatening environment in a virtual classroom since the environment also affects students' learning motivation.

Secondly, teachers are to be oriented that they should give students the freedom to choose their preferred flexible learning modality which is either through online or modular learning. This is because several students struggle when learning during synchronous sessions due to problems in internet connectivity. Apparently, the data shows that the poor and unstable internet connectivity seems to be the major problem faced by students that leads to their lack of motivation and unwillingness to learn online.

Lastly, students' motivations and amotivations vary and are influenced by the different circumstances brought by online-based learning. Considering the limited studies regarding the motivations and amotivations in online-based learning, further investigations should be done across this field of study to contribute essential information to the existing literature.

\section{References}

[1] Ahmad, M., Ghani, M., \& Malik, A. M. (2020). Exploring the relation between English and online mode of learning during covid-19. Linguistic and Literature Review, 6(2), 109-116.

[2] Al-Maqtri, M. (2014). How effective is e-learning in teaching English? A case study. Journal of Education and Human Development, 3(2), 647669.

[3] Artino, A. R. Jr. (2008). Motivational beliefs and perceptions of instructional quality: Predicting satisfaction with online training. Journal of Computer Assisted Learning, 24(3), 260-270.

[4] Artino, A. R., Jr., \& Stephens, J. M. (2009). Beyond grades in online learning: Adaptive profiles of academic self-regulation among naval academy undergraduates. Journal of Advanced Academics, 20(4), 568-601.

[5] Ashton, J. (2014). Using multimedia to build a sense of community with online distance learners. Journal of Instructional Research, 3, 97-106.

[6] Bakar, R. (2014). The effect of learning motivation on student's productive competencies in vocational high school, West Sumatra. International Journal of Asian Social Science, 4(6), 722-732.

[7] Banditvilai, C. (2016). Enhancing students' language skills through blended learning. The Electronic Journal of e-Learning, 14(3), 220-229.

[8] Bekele, T. A. (2010). Motivation and satisfaction in internet-supported learning environments: A review. International Forum of Educational Technology \& Society, 13(2), 116-127.

[9] Blackmon, S., \& Major, C. (2012). Students experiences in online courses: A qualitative research synthesis. The Quarterly Review of Distance Education, 13(2), 77-85.

[10] Blake, R. (2011). Current trends in online language learning. Annual Review of Applied Linguistic, 3, 19-35.

[11] Brewer, E. W., \& Burgess, D. N. (2005). Professor's role in motivating students to attend class. Journal of Industrial Teacher Education, 42(3), 24.

[12] Chalak, A., \& Jamalifar, G. (2014). The use of internet in English language learning: Practices, attitudes, and challenges of the learners. Advances in English language and literature, 1(2), 1-6.

[13] Chong, M.Y., Renandya, W., \& Ng, Q. (2019). Demotivation in L2 classrooms: Teacher and learner factors. Language Education and Acquisition Research Network Journal, 12(2), 64-75.

[14] Dağgöl, G. (2013). The reasons of lack of motivation from the students and teachers voices. The Journal of Academic Social Science, 1(1), 35-45.

[15] Daneshdoust, B., \& Hagh, M.K. (2012). The advantages and disadvantages of internet-based language learning. Procedia - Social and Behavioral Sciences, 31, 607-611.

[16] Dimora, E.M., \& Nedeva, V. (2010). Some advantages of e-learning in English language training. Trakia Journal of Sciences, 8(3), 21-28.

[17] Dhull, P., \& Sakshi, MS. (2017). Online learning. International Education \& Research Journal, 3(4), 32-34.

[18] Ettikan, I., Musa, S.A., \& Alkassim, R.S. (2016). Comparison of convenience sampling and purposive sampling. American Journal of Theoretical and Applied Statistics, 5(1), 1-4.

[19] Everett, D. (2015). Adding value: Online student engagement. Information Systems Education Journal (ISEDJ), 13(6), 69-76. 
[20] Falloon, G. (2012). Inside the virtual classroom: Student perspectives on affordances and limitations. Journal of Open, Flexible and Distance Learning, 16(1), 108-1

[21] Fandiño, F.G., Muñoz, L., \& Velandia, A.J. (2019). Motivation and e-learning English as a foreign language: A qualitative study. Heliyon, 5, 1-7.

[22] Fullerton, S., Taylor, D., \& Watson, J. (2009).Web-based instruction \& online delivery of classes: Where are we now? American Journal of Business Education, 2(1), 91-100.

[23] Gardner, R. C. \& Lambert, W. E. (1972). Attitudes and motivation in second language learning. New York: Newbury House Publishers.

[24] Gedera, D. (2014). Students' experiences of learning in a virtual classroom. International Journal of Education and Development using Information and Communication Technology, 10(4), 93-101.

[25] Gholami, R., Allahyar, N., \& Rafik-Galea, S. (2012). Integrative motivation is an essential determinant of achievement: A case of EFL high school students. World Applied Sciences Journal, 17(11), 1416-1424.

[26] Gustiani, S. (2020). Students' motivation in online learning during the covid-19 pandemic era: A case study. HOLISTICS JOURNAL, 12(2), 2340.

[27] Hartnett, M. (2012). Relationships between online motivation, participation, and achievement: More complex than you might think. Journal of Open, Flexible, and Distance Learning, 16(1), 28-41.

[28] Hartnett, M. (2016). The importance of motivation in online learning. Motivation in online education, 5-32.

[29] Hassenburg, A. (2009). Distance education versus the traditional classroom. Berkeley Scientific Journal, 13(1), 7-10.

[30] Islam, S., Chowdhury, S., \& Islam, A. (2009). Lix education in an e-learning environment: Problems and proposal for Bangladesh. Asia Pacific Conference on Library \& Information Education \& Practice, 519-529.

[31] Jamshed, S. (2014). Qualitative research method-interviewing and observation. Journal of Basic and Clinical Pharmacy, 5(4), 87-88.

[32] Jan, A. (2020). A phenomenological study of synchronous teaching during covid-19: A case of an international school in Malaysia. Social Sciences \& Humanities, 2, 1-10.

[33] Kebritchi, M., Lipschuetz, A., \& Santiague, L. (2017). Issues and challenges for teaching successful online courses in higher education: A literature review. Journal of Educational Technology Systems, 6(1) 4-29.

[34] Kerr, M., Rynearson, K. \& Kerr, M. (2006). Student characteristics for online learning success. The Internet and Higher Education, 9(2), 91-105.

[35] Khan, M. A., Vivek., Nabi, M. K., Khojah, M., \& Tahir, M. (2021). Students' perception towards e-learning during the covid-19 pandemic in India: An empirical study. Sustainability, 13, 1-14.

[36] Kim, K.J., \& Frick, T. W. (2011). Changes in student motivation during online learning. Journal of Educational Computing Research, 44(1), 123.

[37] Krishnan, I. A., Ching, H.S., Ramalingam, S.J., Maruthai, E., Kandasamy, P., De Mello, G., Munian, S., \& Ling, W.W. (2020). Challenges of learning English in the 21st century: Online vs. traditional during covid-19. Malaysian Journal of Social Sciences and Humanities, 5(9), 1-15.

[38] Kuama, S., \& Intharaksa, U. (2016). Is online learning suitable for all English students? PASAA, 52, 54-82.

[39] Lai, C.C., \& Kritsonis, W. (2006). The advantages and disadvantages of computer technology in second language acquisition. Doctoral Forum National Journal for publishing and mentoring student research, 3(1), 1-5.

[40] Lee, J., \& Martin, L. (2017). Investigating students' perceptions of motivating factors of online class discussions. International Review of Research in Open and Distributed Learning, 18(5), 148-172.

[41] Lin, C.-H., Zhang, Y., \& Zheng, B. (2017). The roles of learning strategies and motivation in online language learning: A structural equation modeling analysis. Computers \& Education, 113, 75-85.

[42] Lumsden, L. (1994). Student motivation to learn. ERIC Digest, 92, 1-7.

[43] Mahadi, T.S. \& Jafari, S. (2012). Motivation, its types, and its impacts in language learning. International Journal of Business and Social Science, 3(24), 230-235.

[44] Martinez, I.R. \& Esparcia, J. (2020). Internet access in rural areas: Brake or stimulus as a post-COVID-19 opportunity? Sustainability, 12(0), 117.

[45] Mohammadi, N., Ghorbani, V., \& Hamidi, F. (2011). Effects of e-learning on language learning. Procedia Computer Science, 3, 464-468.

[46] Mohd Salman, A. M., \& Aziah, I. (2012). Learning styles and perception of engineering students towards online learning. Procedia-Social and Behavioral Sciences, 69, 669-674.

[47] Moules, N., Norris, J., Nowell, L., \& White, D. (2017).Thematic analysis striving to meet trustworthiness criteria. International Journal of Qualitative Method, 6, 1-13.

[48] Murugachandravel, J. (2019). Trends in virtual classrooms. GRD Journals- Global Research and Development Journal for Engineering, 4(7), 1618.

[49] Nguyen, H. (2019). Motivation in learning the English language: A case study at Vietnam national university, Hanoi. European Journal of Educational Sciences, EJES, 6 (1), 49-65.

[50] Pekrun, R., Lichtenfeld, S., Marsh, H. W., Murayama, K., \& Goetz, T. (2017). Achievement emotions and academic performance: Longitudinal models of reciprocal effects. Child Development, 88(5), 1653-1670.

[51] Ryan, R. M., \& Deci, E. L. (2000a). Intrinsic and extrinsic motivations: Classic definitions and new directions. Contemporary Educational Psychology, 25(1), 54-67.

[52] Ryan, R. M., \& Deci, E. L. (2000b). Self-determination theory and the facilitation of intrinsic motivation, social development, and well-being. American Psychologist, 55(1), 68-78.

[53] Selvi, K. (2010). Motivating factors in online courses. Procedia Social and Behavioral Sciences, 2, 819-824.

[54] Soni, S., \& Dubey, S. (2019). Towards systematic literature review of e-learning. International Journal of Scientific Research in Computer Science, Engineering and Information Technology, 3(3), 1389-1396.

[55] Topkaya, E.Z., \& Erarslan, A. (2017). EFL students' attitudes towards e-learning and effect on an online course on students' success in English. The Literacy Trek, 3(2), 80-101.

[56] Tria, J. (2020). The covid -19 pandemic through the lens of education in the Philippines: The new normal. International Journal on Pedagogical Development and Lifelong Learning, 1(1),1-4. 
[57] Ushida, E. (2005). The role of students' attitudes and motivation in second language learning in online language courses. CALICO Journal, 23(1), 49-78.

[58] Vallerand, R.J. (1997). Towards a hierarchical model of intrinsic and extrinsic motivation. In M.P. Zanna (Ed.), Advances in experimental social psychology, 29, 271- 360.

[59] Xenos, M. (2018). The future of virtual classrooms: Using existing features to move beyond the traditional classroom. Limitations. In: Auer M., Tsiatsos T. (eds) Interactive Mobile Communication Technologies and Learning, 725, 944-951.

[60] Yadav, M., \& BaniAta, H. (2013). Factorizing demotivation, finding motivation: A constructive approach to quality enhancement. ProcediaSocial and Behavioral Sciences, 70, 120-130.

[61] Yang, Y., \& Cornelius, L. (2004). Students perception towards the quality of online education: A qualitative approach. Association for Educational Communications and Technology, 861-876.

[62] Yılmaz, M. B. (2017). The Relation between academic procrastination of university students and their assignment and exam performances: The situation in the distance and face-to-face learning environments. Journal of Education and Training Studies, 5(9), 146-157.

[63] Yuyun, I. (2013). E-language learning program: Problems and challenges. TEFLIN International Conference, 2, 1-7. 